\title{
Hubungan Kadar Leptin Serum dengan Kompleksitas Lesi Koroner berdasarkan Skor SYNTAX pada Penderita Penyakit Arteri Koroner Stabil
}

\author{
Fajar Ashari, ${ }^{1}$ Toni Mustahsani Aprami, ${ }^{2}$ Muhammad Rizki Akbar, ${ }^{2}$ Augustine Purnomowati ${ }^{2}$ \\ Januar Wibawa Martha, ${ }^{2}$ Chaerul Achmad, ${ }^{2}$ Erwan Martanto ${ }^{2}$ \\ ${ }^{1}$ Rumah Sakit Al-Islam Bandung, ${ }^{2}$ Departemen Ilmu Penyakit Dalam Fakultas Kedokteran Universitas Padjadjaran \\ Rumah Sakit Dr. Hasan Sadikin Bandung
}

\begin{abstract}
Abstrak
Leptin memiliki peran penting dalam pembentukan plak ateroskleosis dengan mengaktifkan respons sel imun dan respons inflamasi ataupun peran langsung terhadap dinding pembuluh darah koroner. Penelitian terdahulu mengenai hubungan antara kadar leptin serum dan kompleksitas lesi koroner masih menunjukkan kontroversi. Penelitian ini bertujuan mengetahui hubungan antara kadar leptin serum dan kompleksitas lesi koroner berdasarkan skor SYNTAX pada penderita penyakit arteri koroner stabil. Metode penelitian berupa observasional, deskriptif, dan analisis korelasi dengan rancangan potong lintang. Subjek penelitian sebanyak 44 orang penderita penyakit arteri koroner (PAK) stabil yang memenuhi kriteria inklusi, menjalani pemeriksaan angiografi koroner di Rumah Sakit Dr. Hasan Sadikin Bandung selama bulan Januari-Mei 2014. Pengambilan sampel darah untuk pemeriksaan kadar leptin serum dilakukan sebelum tindakan angiografi. Kompleksitas lesi arteri koroner dinilai menggunakan skor SYNTAX. Hasil penelitian didapatkan subjekpenelitian 84\% laki-laki dengan usia rata-rata 54,68 $( \pm 10,24)$ tahun. Indeks massa tubuh rata-rata $24,71( \pm 3,05) \mathrm{kg} / \mathrm{m}^{2}$. Faktor risiko terbanyak adalah dislipidemia (84\%), merokok (72\%), hipertensi (38,4\%), diabetes melitus (22,7\%), dan obesitas (4,5\%). Median kadar leptin serum $7.242(780-36.929) \mathrm{pq} / \mathrm{mL}$, nilai rata-rata skor SYNTAX sebesar $19,52( \pm 9,93)$. Analisis menggunakan uji korelasi rank-Spearman tidak didapatkan hubungan $(\mathrm{p}=0,61 ; \mathrm{r}=0,078)$. Perbedaan hasil penelitian ini dengan penelitian sebelumnya disebabkan oleh perbedaan subjek dan kriteria penilaian kompleksitas lesi arteri koroner. Simpulan, tidak terdapat hubungan antara kadar leptin serum dan kompleksitas lesi koroner berdasarkan skor SYNTAX pada penderita penyakit arteri koroner stabil. [MKB. 2016;48(1):26-31]
\end{abstract}

Kata kunci: Kompleksitas lesi koroner, leptin serum, penyakit arteri koroner stabil, skor SYNTAX

\section{Correlation between Serum Leptin Levels and Complexity of Coronary Artery Lesion based on SYNTAX Score in Patients with Stable Coronary Artery Disease}

\begin{abstract}
Leptin has been shown to play a potential role in the atherosclerotic plaque formation by activating immune and inflammatory cells or directly acting on the vessel wall. Earlier reports of the correlation of serum leptin levels with the degree of coronary lesion stated are still controversial. This study determined the correlation between serum leptin levels and complexity of coronary artery lesion in patients with stable coronary artery disease (SCAD). This is an observational cross-sectional study. Data were collected from January to May 2014 in Dr. Hasan Sadikin Central General Hospital Bandung. Blood samples were collected before angiography procedures. The complexity of coronary artery lesion was assessed using SYNTAX score. There were 44 patients who met inclusion criteria, male 84\%, median age $54.68(+10.24)$ years. Mean body mass index $24.71(+3.05) \mathrm{kg} / \mathrm{m} 2$. Dyslipidemia was the most common risk factor (84\%), followed by smoking (72\%), hypertension (38.4\%), diabetes mellitus (22.7\%), and obesity (4.5\%). Median leptin level was 7,242 (780-36,929) pq/mL. Mean SYNTAX score was 19.52 $(+9.93)$. Leptin level had no correlation with the complexity of coronary artery lesion $(p=0.61, r=0.078)$. The difference between this study from prior studies might be caused by differences in subject selection and criteria used for complexity of coronary artery lesion. In conclusion, there is no correlation between serum leptin levels and complexity of coronary artery lesion in patients with stable coronary artery disease. [MKB. 2016;48(1):2631]
\end{abstract}

Key words: Complexity of coronary artery lesion, leptin, stable coronary artery disease, SYNTAX score

Korespondensi: Fajar Ashari, dr., Rumah Sakit Al-Islam Bandung Jalan Soekarno-Hatta No.644 Bandung, mobile 08122336434, e-mail fashr35@gmail.com 


\section{Pendahuluan}

Penyakit arteri koroner (PAK) adalah merupakan penyebab utama kematian dan kecacatan di negara maju dan negara berkembang. Penyakit arteri koroner menjadi penyebab kematian 1 dari 6 penduduk Amerika Serikat pada tahun 2009. Penduduk Amerika yang mengalami serangan jantung diperkirakan setiap 34 detik ada 1 orang dan terdapat 1 penduduk Amerika meninggal karena PAK setiap menit. ${ }^{1}$

Profil kesehatan Indonesia pada tahun 2009 memperlihatkan penyakit sistem kardiovaskular merupakan penyakit utama penyebab kematian di rumah sakit pada tahun 2007 maupun tahun 2008. ${ }^{2}$ Penyakit jantung pada orang dewasa di Indonesia berdasarkan riset kesehatan dasar (Riskesdas) tahun 2013 masih menunjukkan penyakit jantung koroner termasuk dalam 10 besar penyakit tidak menular paling banyak di Indonesia. $^{3}$

Patomekanisme PAK melibatkan adipositas sebagai salah satu faktor yang berperan dalam proses aterosklerosis. Jaringan adiposa diketahui berfungsi sebagai sistem hormonal yang secara aktif menyekresikan berbagai protein seperti adipositokin yang memiliki sifat proinflamasi dan juga proaterosklerosis. ${ }^{4}$ Leptin merupakan salah satu adipositokin yang memiliki peran pada sistem kardiovaskular, yaitu mengaktifkan respon simpatis, efek presor, regulasi fungsi endotel vaskular, dan inflamasi vaskular serta pembentukan plak yang berperan dalam proses aterosklerosis. ${ }^{5,6}$ Leptin berperan menstimulasi inflamasi pembuluh darah, stres oksidasi, dan hipertropi otot polos pembuluh darah yang diduga berhubungan dengan patogenesis terjadi diabetes melitus tipe 2, hipertensi, aterosklerosis, dan PAK..$^{7-10}$

Penilaian prognostik PAK stabil merupakan bagian yang penting penatalaksanaan pasien. Panduan tatalaksana PAK stabil yang dirilis oleh European Society of Cardiology (ESC) tahun 2013 menyatakan prognosis akan memburuk pada pasien dengan semakin kompleksnya lesi koroner. ${ }^{11}$ Angiografi koroner merupakan pemeriksaan baku emas dalam menilai lesi koroner. Skor SYNTAX mempunyai berbagai kelebihan di dalam menilai kompleksitas lesi koroner, yaitu lebih komprehensif dan aplikatif di dalam menilai kompleksitas stenosis arteri koroner serta dapat direkomendasikan sebagai salah satu sistem skoring di dalam panduan tatalaksana PAK stabil menurut ESC. ${ }^{12}$ Skor SYNTAX dikembangkan dari beberapa klasifikasi angiografi sebelumnya yang memiliki tujuan mengelompokkan anatomi koroner berdasarkan jumlah lesi dan akibat fungsionalnya, lokasi, dan kompleksitas lesi tersebut.

Khafaji dkk. ${ }^{13}$ yang meneliti hubungan kadar leptin dengan hasil angiografi berdasarkan atas kriteria Coronary Artery Surgery Study (CASS) pada pasien sindrom koroner akut, didapatkan hasil bahwa tidak terdapat hubungan antara kadar leptin dan jumlah arteri koroner yang mengalami aterosklerosis $(\mathrm{p}=0,6)$.

Penelitian oleh Ali dkk. ${ }^{14}$ mempergunakan kriteria penilaian kompleksitas berdasarkan Bogaty, sedangkan pada penelitian Dubey dkk. ${ }^{15}$ menggunakan kriteria kompleksitas berdasarkan Ambrose, mereka memperlihatkan bahwa leptin memiliki hubungan dengan beratnya lesi dan kompleksitas lesi koroner sehingga disimpulkan tingginya kadar leptin merupakan prediktor berat lesi koroner.

Pemeriksaan leptin merupakan suatu metode pemeriksaan noninvasif yang dapat dijadikan prediktor kompleksitas lesi koroner. ${ }^{14,15}$ Terdapat perbedaan hasil penelitian mengenai hubungan kadar leptin serum dengan kompleksitas lesi arteri koroner. Selain itu, leptin dapat dijadikan prediktor kompleksitas lesi koroner yang juga merupakan pemeriksaan noninvasif, oleh sebab itu dilakukan penelitian untuk dapat mengetahui apakah ada hubungan kadar leptin serum dengan kompleksitas lesi koroner pada penderita PAK stabil yang dinilai berdasarkan skor SYNTAX.

\section{Metode}

Subjek penelitian adalah penderita PAK stabil yang menjalani pemeriksaan angiografi di RSUP Dr. Hasan Sadikin Bandung yang telah memenuhi kriteria inklusi dan tidak termasuk eksklusi. Kriteria inklusi penelitian ialah penderita PAK stabil (Canadian Cardiovascular Society/CCS I, II, III) ${ }^{11}$ baik laki-laki maupun perempuan yang telah menjalani pemeriksaan angiografi koroner dengan stenosis $>50 \%$ pada satu pembuluh darah atau lebih atau penyakit left main. Kriteria eksklusi adalah penderita dengan sindrom koroner akut, riwayat bedah pintas koroner, riwayat intervensi koroner per kutan, dan gagal ginjal kronik.

Penelitian ini merupakan penelitian yang observasional, deskriptif, dan analitik korelasi menggunakan rancangan potong lintang. Analisis bivariabel mempergunakan analisis korelasi uji Pearson jika data berdistribusi normal atau uji rank Spearman jika data tidak berdistribusi normal. Penelitian ini dilaksanakan di Divisi 
Tabel 1 Karakteristik Dasar Subjek Penelitian

\begin{tabular}{lcc}
\hline \multicolumn{1}{c}{ Variabel } & $\begin{array}{c}\text { Rata-rata(SD)/ } \\
\text { Median (Min-Maks) }\end{array}$ & $\begin{array}{c}\text { Jumlah (\%) } \\
(\mathbf{n}=\mathbf{4 4})\end{array}$ \\
\hline Usia (tahun) & $54,68( \pm 10,24)$ & $37(84)$ \\
Jenis kelamin (laki-laki) & $1,6( \pm 0,07)$ & \\
Tinggi badan (meter) & $66,7( \pm 10,7)$ & $2(4,5)$ \\
Berat badan (kg) & $24,71( \pm 3,05)$ & $32(72)$ \\
IMT $\left(\mathrm{kg} / \mathrm{m}^{2}\right)$ & & $10(22,7)$ \\
Obesitas & & $17(38,6)$ \\
Merokok & & $37(84)$ \\
Diabetes melitus & & \\
Hipertensi & & \\
Dislipidemia & $7.242(780-36.929)$ & \\
Leptin $(\mathrm{pg} / \mathrm{mL})$ & $19,52( \pm 9,93)$ & \\
SYNTAX & & \\
\hline
\end{tabular}

Diagnostik Invasif Departemen Kardiologi dan Kedokteran Vaskular Rumah Sakit Dr. Hasan Sadikin Bandung pada bulan Januari sampai dengan November 2014.

\section{Hasil}

Usia rata-rata penderita PAK pada penelitian ini adalah 54,68 $\pm 10,24$ tahun dengan usia ratarata penderita laki-laki 52 tahun, sedangkan perempuan 61 tahun. Sebagian besar subjek penelitian laki-laki sebanyak 37 orang (84\%) dibanding dengan perempuan 7 orang (16\%). Karakteristik dasar pasien yang menjadi subjek penelitian tampak pada Tabel 1 .

Uji normalitas data memperlihatkan leptin

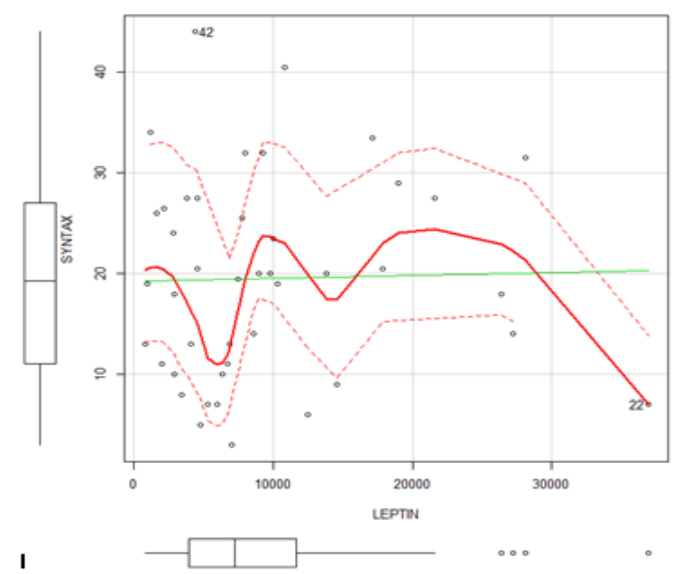

Gambar 1 Hubungan Kadar Leptin dengan Skor SYNTAX tidak berdistribusi normal dengan median 7.242 $\mathrm{pg} / \mathrm{mL}$ dengan rentang (780-36.929 pg/mL). Skor SYNTAX memiliki rata-rata 19,52 $( \pm 9,93)$. Analisis untuk mengetahui hubungan antara leptin dan skor SYNTAX dilakukan menggunakan uji korelasi rank-Spearman. Analisis hubungan kadar leptin dengan skor SYNTAX dapat dilihat pada Gambar ( $\mathrm{p}=0,61 ; \mathrm{r}=0,078)$.

Uji korelasi rank Spearman memperlihatkan hubungan antara kadar leptin serum dan skor SYNTAX yang tidak bermakna $(p=0,61 ; r=0,078)$, tidak terdapat hubungan antara kadar leptin serum dan kompleksitas lesi koroner pada penderita PAK stabil yang dinilai menggunakan skor SYNTAX.

\section{Pembahasan}

Data usia dan jenis kelamin pada Tabel 1 sesuai dengan data pada penelitian oleh Ali dkk. ${ }^{14}$ bahwa usia rata-rata 55,7 \pm 12 tahun dan komposisi lakilaki lebih banyak, yaitu 86\% dibanding dengan perempuan pada penderita PAK yang telah menjalani angiografi koroner. Penelitian Dubey dkk. ${ }^{15}$ menunjukkan usia rata-rata subjek lebih tinggi (58+12 tahun), sedangkan komposisi lakilaki lebih banyak dibanding dengan perempuan, yaitu $77 \%$. Khafaji dkk. ${ }^{13}$ memperlihatkan usia rata-rata subjek penelitian lebih banyak pada kelompok usia $\leq 50$ tahun (55\%), sedangkan komposisi laki-laki sebesar 93\%. Sesuai dengan hasil penelitian tersebut bahwa usia rata-rata hampir sama dan prevalensi laki-laki lebih banyak daripada perempuan.

Faktor risiko terbanyak pada penelitian ini 
adalah hipertensi, sesuai dengan hasil penelitian Ali dkk. ${ }^{14}$ sebesar $60 \%$ dan Dubey dkk. ${ }^{15}$ sebesar $66 \%$. Pada penelitian Khafaji dkk. ${ }^{13}$ diabetes melitus merupakan faktor risiko terbanyak sebesar 38\%.

Hasilpenelitianinimendukunghasilpenelitian sebelumnya yang dilakukan oleh Khafaji dkk. ${ }^{13}$ yang meneliti hubungan antara peningkatan kadar leptin dan hasil angiografi pada pasien sindrom koroner akut, didapatkan hasil bahwa terdapat kecenderungan peningkatan kadar leptin serum dengan peningkatan jumlah arteri koroner yang mengalami aterosklerosis, namun hasil ini secara statistik tidak berhubungan. Perbedaan penelitian Khafaji dkk. ${ }^{13}$ dengan penelitian ini adalah pada subjek penelitian Khafaji dkk. mempergunakan pasien sindrom koroner akut (SKA) dan juga kriteria penilaian angiografi dengan Coronary Artery Surgery Study (CASS) yang menilai berdasarkan beratnya stenosis, yaitu $50 \%$ di left main serta $70 \%$ di cabang utama, dan kriteria luas lesi berdasarkan jumlah arteri yang mengalami stenosis. Kriteria eksklusi penelitian Khafaji dkk. ${ }^{13}$ adalah pasien dengan gangguan fungsi ginjal dan memiliki keterbatasan penelitian karena jumlah sampel penelitian yang kecil hanya 34 pasien.

Perbedaan dari hasil penelitian mengenai hubungan antara kadar leptin serum dan kompleksitas lesi koroner didapatkan dari penelitian sebelumnya yang dilakukan oleh Ali dkk. ${ }^{14}$ dan Dubey dkk. ${ }^{15}$ yang menyatakan leptin mempunyai peran pada proses aterosklerosis, tetapi juga berperan dalam beratnya lesi, luas lesi, dan kompleksitas lesi koroner. ${ }^{14,15}$

Perbedaan penelitian ini dengan penelitian oleh Ali dkk. ${ }^{14}$ adalah subjek yang dicurigai menderita PAK dan menjalani angiografi koroner dengan kriteria eksklusi adalah pasien dengan penyakit inflamasi, keganasan, pasien kelainan katup jantung, ataupun telah menjalani prosedur revaskularisasi sebelumnya. Perbedaan lainnya adalah kriteria angiografi untuk menilai derajat lesi arteri koroner berdasarkan kriteria dari Bogaty. Penilaian angiografi berdasarkan atas beratnya lesi jika terdapat stenosis lebih dari $70 \%$ atau $50 \%$ pada left main. Hasil penelitian menunjukkan bahwa kadar leptin yang tinggi berhubungan dengan beratnya penyempitan lesi koroner $(r=0,43 ; p<0,0001)$, luas lesi koroner $(\mathrm{r}=0,40 ; \mathrm{p}<0,0001)$, dan kompleksitas/pola lesi koroner $(r=0,45 ; p<0,0001){ }^{14}$

Perbedaan penelitian ini dengan penelitian Dubey dkk. ${ }^{15}$ adalah subjek yang merupakan pasien angina pektoris tidak stabil yang telah menjalani angiografi dan hasilnya menunjukkan bahwa kadar leptin lebih tinggi secara signifikan pada populasi dengan lesi koroner yang cukup kompleks dibanding dengan populasi dengan lesi koroner simpel $(13,43 \pm 5,26 \mathrm{ng} / \mathrm{mL}$ vs $9,45 \pm 4,18 \mathrm{ng} / \mathrm{mL}, \mathrm{p}=<0,01)$. Kadar leptin pada lesi koroner kompleks secara signifikan lebih tinggi dibanding dengan kontrol $(13,43 \pm 5,26$ $\mathrm{ng} / \mathrm{mL}$ vs $5,08 \pm 2,81 \mathrm{ng} / \mathrm{mL} ; \mathrm{p}<0,001)$. Analisis multivariabel menunjukkan leptin merupakan prediktor independen untuk suatu morfologi lesi koroner yang kompleks $(p=0,019)$. Penelitian Dubey dkk. ${ }^{15}$ menilai lesi koroner hanya dari lesi culprit, tidak memperhitungkan lesi lain di luar lesi yang menjadi penyebab serangan akut, tidak memperhitungkan lesi lain di luar lesi tersebut. Kriteria morfologi lesi koroner pada penelitian Dubey dkk. ${ }^{15}$ menggunakan kriteria yang digunakan oleh Ambrose, yaitu kriteria lesi dibagi menjadi lesi simpel dan kompleks. ${ }^{15}$ Perbedaan lainnya, yaitu pada penelitian Dubey dkk. penilaian kompleksitas dilakukan oleh 2 orang kardiologis intervensi, sedangkan pada penelitian ini hanya dilakukan oleh satu orang.

Penilaian menggunakan skor SYNTAX lebih komprehensif dengan cara mempertimbangkan kelainan struktural seperti letak lesi, beratnya angulasi pembuluh koroner, percabangan dari lokasi lesi, kolateral, beratnya kalsifikasi lesi, dan trombus, yang tidak diperhitungkan pada penelitian-penelitian sebelumnya. ${ }^{12}$ Perbedaan kriteria penilaian antara penelitian juga dapat menyebabkan perbedaan hasil hubungan antara kadar leptin dan kompleksitas lesi koroner.

Leptin sebagai hormon yang berperan dalam metabolisme kalori mempunyai siklus sirkadian yang dapat memengaruhi hasil pemeriksaan kadar leptin serum. Pengambilan leptin serum pada penelitian ini, yaitu bervariasi antara pagi, siang, maupun sore hari. Perbedaan waktu pengambilan mungkin mampu memengaruhi kadar leptin. Kadar leptin serum selain memiliki siklus sirkardian, yang kadarnya dipengaruhi fase akut PAK. Penelitian Khafaji dkk..$^{13}$ dengan subjek penderita SKA memperlihatkan kadar leptin meningkat dengan puncaknya pada 36 jam perawatan dan menurun secara bertahap setelahnya. Penelitian Krasnodebski dkk. ${ }^{16}$ yang membandingkan kadar leptin pada periode awal SKA dan masa pemulihan pada populasi dengan diabetes melitus juga menunjukkan kadar yang signifikan lebih tinggi di fase awal dibanding dengan fase pemulihan. ${ }^{16}$ Penelitian Ali dkk. ${ }^{14}$ hasil penelitiannya menunjukkan bahwa pasien dengan angina tidak stabil dan infark miokardium sebelumnya merupakan prediktor independen terhadap kompleksitas lesi koroner. ${ }^{16}$ Penelitian- 
penelitian tersebut menunjukkan bahwa kadar leptin memiliki hubungan signifikan pada fase akut dibanding dengan dengan fase pemulihan.

Penilaian hasil angiografi dapat dipengaruhi oleh perbedaan penilaian baik intra-observer atupun inter-observer. Penelitian oleh Nau dkk. ${ }^{17}$ yang menilai perbedaan penilaian hasil angiografi inter-observer terhadap skor SYNTAX memperlihatkan inter-observer variability yang dapat diterima dengan nilai kappa 0,7. Nau dkk. ${ }^{17}$ menyarankan penilaian dengan standar interpretasi yang baik dan gambaran lesi yang terintegrasi dapat mengurangi perbedaan pada penilaian skor SYNTAX. Serruys dkk. ${ }^{18}$ pada penelitiannya menunjukkan secara global nilai kappa intra-observer variability sebesar 0,45 dan juga intra-observer variability sebesar 0,59. Penggunaan nilai skor SYNTAX rata-rata oleh beberapa penilai dapat memberikan interpretasi yang lebih baik jika dibanding dengan oleh seorang penilai. Penilaian hasil angiografi pada penelitian ini dilakukan oleh satu orang penilai, pada penelitian Dubey dkk. dilakukan oleh 2 orang penilai, keadaan ini memungkinkan terjadi perbedaan dalam menilai hasil angiografi.

Kadar leptin serum pada penelitian ini memiliki median $7.242 \mathrm{pg} / \mathrm{mL}$ dengan rentang yang sangat lebar, yaitu nilai terkecil 780 pg/ $\mathrm{mL}$ dan nilai terbesar $36.929 \mathrm{pg} / \mathrm{mL}$. Subjek penelitian dengan kadar leptin serum yang sangat kecil ada 2 orang, yaitu $979 \mathrm{pg} / \mathrm{mL}$ dan $780 \mathrm{pg} / \mathrm{mL}$. Nilai leptin yang sangat rendah pada kedua subjek penelitian ini disebabkan oleh keduanya memiliki nilai indeks massa tubuh yang kecil. Nilai leptin dengan rentang yang sangat lebar pada penelitian ini dapat memengaruhi hasil analisis hubungan antara leptin serum dan kompleksitas lesi koroner. Simpulan, tidak terdapat hubungan antara kadar leptin serum dan kompleksitas lesi koroner berdasarkan skor SYNTAX pada penderita penyakit arteri koroner stabil.

\section{Daftar Pustaka}

1. Go AS, Mozaffarian D, Roger VL, Benjamin EJ, Berry JD, Blaha MJ, dkk. Heart disease and stroke statistics-2014 update: a report from the American Heart Association. Circulation. 2013;127:e6-245.

2. Badan Penelitian dan Pengembangan Kementerian Kesehatan RI. Profil Data Kesehatan Indonesia Tahun 2009. Jakarta: Kementerian Kesehatan Republik Indonesia; 2010.
3. Badan Penelitian dan Pengembangan Kementerian Kesehatan RI. Riset Kesehatan Dasar 2013. Jakarta: Kementerian Kesehatan Republik Indonesia; 2013.

4. Zhang H, Cui J, Zhang C. Emerging role of adipokines as mediators in atherosclerosis. World J Cardiol. 2010;2(11):370-6.

5. Koh KK, Park SM, Quon MJ. Leptin and cardiovascular disease: response to therapeutic interventions. Circulation. 2008; 117(25):3238-49.

6. Yang Z, Ming XF. Recent advances in understanding endothelial dysfunction in atherosclerosis. Clin Med Res. 2006;4(1):5365.

7. Beltowski J, Wojcicka G, Marciniak A, Jamroz A. Oxidative stress, nitric oxide production, and renal sodium handling in leptin-induced hypertension. Life Sci. 2004;74(24):29873000.

8. Beltowski J. Leptin and atherosclerosis. Atherosclerosis. 2006;189(1):47-60.

9. Beltowski J. Role of leptin in blood pressure regulation and arterial hypertension. J Hypertens. 2006;24(5):789-801.

10. Dubey L, Hesong Z. Role of Leptin in atherogenesis. Exp Clin Cardiol. 2006;11(4): 269-75.

11. Montalescot G, Sechtem U, Achenbach S, Andreotti F, Arden C, Budaj A, dkk. 2013 ESC guidelines on the management of stable coronary artery disease. Eur Heart J. 2013; 34(8):2949-3003.

12. Sianos G, Morel MA, Kappetein AP, Morice MC, Colombo A, Dawkin K, dkk. The SYNTAX score: an angiographic tool grading the complexity of coronary artery disease. Eur Interv. 2005;1(2):219-7.

13. Khafaji HAR, Bener AB, Rizk NM, Suwaidi JA. Elevated serum leptin levels in patients with acute myocardial infarction; correlation with coronary angiographic and echocardiographic findings. BMC Research. 2012;5:262-70.

14. Ali HH, Mottaleb NA, Hamed HB, Elsayed AA. Serum adiponectin and leptin as predictors of the presence and degree of coronary atherosclerosis. Coron Artery Dis. 2011;22(4):264-9.

15. Dubey L, Zeng H, Hashmi S, Hongjie W, Tao H. Association of plasma leptin levels and complexity of the culprit lesion in patients with unstable angina. Int J Cardiol. 2008;126(2):183-9.

16. Krasnodebski P, Bak MI, Opolski G, Karnafel W. Leptin in acute myocardial infarction 
and period of convalescence in patients with type 2 diabetes mellitus. Cardiol Pol. 2010:68(6):648-53.

17. Nau G, Lamelas P, Albertal M, Belardi J, Padilla L, Peralta S, dkk. Per-lesion inter-observer variability and impact on syntax score. J Am
Coll Cardiol. 2012;60:175.

18. Serruys P, Onuma Y, Garg S, Sarno G, Brand M, Kappetein AP, dkk. Assessment of the SYNTAX score in the SYNTAX study. Eur Interv. 2009;5(1):50-6. 